\title{
TIPE-TIPE KESALAHAN SINTAKSIS PADA KARANGAN EKSPOSISI SISWA SMA BINA SPORA MANDIRI CIGOMBONG BOGOR
}

\author{
Endang Wiyanti, Sulis Setiawati, Bambang Sumadyo \\ Program Studi Pendidikan Bahasa Indonesia \\ Fakultas Bahasa dan Seni, Universitas Indraprasta PGRI \\ endang_rahmadhani@yahoo.com,sulis2310@yahoo.co.id
}

\begin{abstract}
Abstrak
Tujuan penelitian ini adalah untuk menganalisis kesalahan sintaksis pada karangan eksposisi siswa kelas XI SMA Bina Spora Mandiri Cigombong, Bogor. Metode penelitian yang digunakan adalah metode analisis isi (content analysis) dengan pendekatan kualitatif. Karangan eksposisi siswa yang diteliti berjumlah 31 karangan. Pada karangan tersebut ditemukan sebanyak 92 kalimat salah. Jenis kesalahan sintaksis yang ditemukan terdiri atas kesalahan pada pilihan kata/diksi sebanyak 64 kalimat atau 24,33\%, kalimat yang berstruktur tidak baku sebanyak 62 kalimat atau 23,57\%, kesalahan pada ketidaktepatan bentuk kata sebanyak 53 kalimat atau 20,15\%, kalimat mubazir atau pleonasme sebanyak 44 kalimat atau 16,73\%, \%, kalimat yang tidak memiliki logika atau mengalami kesalahan nalar sebanyak 23 kalimat atau 8,75\%, kontaminasi atau kerancuan kalimat sebanyak 16 kalimat atau 6,08\%, dan kalimat yang ambigu sebanyak 1 kalimat atau 0,38\%. Diharapkan hasil penelitian ini dapat dipergunakan untuk menentukan langkahlangkah dalam proses pembelajaran, menyusun materi pembelajaran secara bertahap dari yang mudah ke yang sukar, dari yang sederhana ke yang rumit, dan sebagainya.
\end{abstract}

Kata Kunci: tipe-tipe kesalahan sintaksis, karangan eksposisi

\begin{abstract}
The purpose of this study is to analyze the syntax error on the exposition of grade XI student in SMA Bina Spora Mandiri Cigombong, Bogor. The method used is content analysis method with qualitative approach. The exposition who research amounted to 31. In the exposition are found 92 sentences with syntax error. Types of errors found the sentence that is not appropriate in the choice of words/diction as many as 64 sentences or 24,33\%, nonstandard sentence structure as much as 62 sentences or $23,57 \%$, consisting of syntax errors in the in appropriateness of the sentence are 53 sentences or $20,15 \%$, redundant sentences or sentence or redundancy as much as 44 sentences or 16,3\%, the sentence that has no logic or reasoning errors as much as 23 sentences or $8,75 \%$, contamination or confusion sentence are 16 sentences or 6,08\%, and an ambiguous sentence is 1 sentences or 0,38\%. We hope this research can be used to determine the steps in the learning process, preparing learning materials gradually from easy to difficult, from simple to complex, and so forth.
\end{abstract}

Keywords: type of syntax error, exposition article

\section{PENDAHULU AN}

Berdasarkan Kurikulum 2013, standar kompetensi mata pelajaran Bahasa Indonesia berorientasi pada hakikat pembelajaran bahasa, yaitu belajar berbahasa adalah belajar berkomunikasi dan belajar sastra adalah belajar menghargai manusia dan nilainilai kemanusiaannya. Oleh karena itu, pembelajaran Bahasa Indonesia diarahkan untuk meningkatkan kemampuan siswa dalam berkomunikasi, baik secara lisan maupun tertulis. 
Ruang lingkup mata pelajaran Bahasa Indonesia meliputi aspek kemampuan berbahasa dan kemampuan bersastra. Aspek kemampuan berbahasa meliputi keterampilan mendengarkan, berbicara, membaca, dan menulis yang berkaitan dengan ragam bahasa nonsastra. Adapun aspek kemampuan bersastra meliputi keterampilan mendengarkan, berbicara, membaca, menulis yang berkaitan dengan ragam sastra. (Permendikbud, 2013:64)

Setiap aspek kemampuan, baik kemampuan berbahasa maupun kemampuan bersastra memiliki standar kompetensi. Standar kompetensi merupakan kualifikasi minimal peserta didik yang menggambarkan penguasaan pengetahuan, keterampilan berbahasa, serta sikap positif terhadap bahasa dan sastra Indonesia. Standar kompetensi ini menjadi acuan bagi guru untuk mengembangkan kompetensi dasar dan materi pembelajaran dalam proses belajar mengajar.

Salah satu standar kompetensi yang harus dikuasai siswa adalah standar kompetensi menulis. Standar kompetensi menulis adalah kualifikasi minimal peserta didik yang menggambarkan penguasaan pengetahuan, keterampilan berbahasa, serta sikap positif terhadap bahasa dan sastra Indonesia secara tertulis. Standar kompetensi menulis ini dipisahkan antara standar kompetensi menulis kemampuan berbahasa dengan standar kompetensi menulis kemampuan bersastra.

Standar kompetensi menulis kemampuan berbahasa dikembangkan dalam kompetensi dasar dan materi pembelajaran menulis. Kompetensi dasar dan materi pembelajaran menulis untuk siswa SMA kelas XI meliputi: menganalisis informasi lisan dan tulis melalui cerita pendek, pantun, cerita ulang, eksplanasi kompleks, dan ulasan/reviu film/drama mengolah, menalar, dan menyajikan informasi lisan dan tulis melalui cerita pendek, pantun, cerita ulang, eksplanasi kompleks, dan ulasan/reviu film/drama. (Permendikbud, 2013:64)

Kemampuan menulis yang sesuai dengan kompetensi dasar dan materi pembelajaran untuk siswa SMA kelas XI dapat dilaksanakan dalam kegiatan mengarang. Mengarang adalah menyusun atau mengorganisasi buah pikiran, ide, atau gagasan ke dalam rangkaian kalimat yang logis dan terpadu dalam bahasa tulisan. Kegiatan mengarang akan menghasilkan sebuah karangan. Karangan ada yang pendek dan ada yang panjang tergantung pada tujuan dan pengembangannya.

Karangan dapat dikembangkan dalam berbagai jenis, seperti karangan jenis narasi, deskripsi, eksposisi, argumentasi, dan persuasi. Setiap jenis karangan memiliki karakteristik tersendiri. Namun kenyataannya, kelima jenis karangan tersebut tidak mungkin dipisahkan secara murni. Misalnya, di dalam karangan eksposisi mungkin terdapat jenis karangan deskripsi, di dalam karangan deskripsi mungkin terdapat jenis karangan narasi, dan sebagainya.

Karangan narasi adalah karangan yang menceritakan sesuatu secara terinci menurut urutan waktu. Karangan deskripsi ialah karangan yang melukiskan sesuatu sehingga pembaca seolah-olah melihat, mendengar, merasakan objek yang dilukiskan. Karangan eksposisi adalah karangan yang memberikan, memaparkan, dan menegaskan sesuatu. Karangan argumentasi adalah karangan yang mengemukakan alasan, contoh, dan bukti untuk meyakinkan pembacanya. Karangan persuasi adalah karangan yang mengungkapkan sesuatu disertai dengan ajakan. 
Salah satu jenis karangan yang dapat dikembangkan sesuai dengan standar kompetensi menulis kemampuan berbahasa kelas XI adalah kemampuan menulis karangan eksposisi. Kemampuan menulis karangan eksposisi adalah keterampilan siswa dalam menguraikan, menjelaskan, dan memaparkan buah pikiran, ide, atau gagasan ke dalam rangkaian kalimat yang logis dan terpadu dalam bahasa tulisan dengan tujuan untuk memberikan informasi.

Dalam mengembangkan buah pikiran, ide, atau gagasan menjadi sebuah karangan eksposisi, siswa memerlukan kemampuan mempergunakan bahasa yang berwujud kata, kalimat, dan makna yang mendukungnya. Bahasa yang dipergunakan dalam karangan eksposisi adalah bahasa ragam formal. Oleh karena itu, bahasa yang dipergunakan harus benar, sesuai dengan kaidah tata bahasa yang berlaku di Indonesia.

Dalam kegiatan belajar mengajar, guru sering menemui kesalahan yang dilakukan siswa, terutama kesalahan tata bahasa. Siswa sering melakukan kesalahan tata bahasa pada kegiatan pembelajaran menulis, khususnya menulis karangan eksposisi. Kesalahan tersebut tentu berpengaruh pada nilai kemampuan menulis yang diperoleh siswa SMA Bina Spora Mandiri Cigombong Bogor.

Pada karangan siswa kelas XI SMA Bina Spora Mandiri Cigombong Bogor, khususnya karangan eksposisi, dijumpai beberapa kesalahan tata bahasa. Kesalahan tata bahasa itu terjadi pada tataran fonologi, morfologi, sintaksis, dan semantik. Hal tersebut menyebabkan nilai yang diperoleh siswa hanya mencapai rata-rata 67, sedangkan Kriteria Ketuntasan Minimal (KKM) standar kompetensi menulis adalah 69.
Pemahaman terhadap kesalahan tata bahasa yang ditemukan pada karangan eksposisi siswa akan memberikan umpan balik bagi penyempurnaan program pengajaran bahasa. Umpan balik tersebut dapat diterapkan dalam perencanaan pengajaran yang lebih baik, penggunaan metode dan teknik mengajar yang lebih tepat, serta penyajian materi yang lebih sistematis. Dengan demikian, proses belajar mengajar berikutnya diharapkan akan lebih berhasil.

Kesalahan tata bahasa yang perlu dianalisis mencakup kesalahan fonologi yang berhubungan dengan kesalahan ujaran atau pelafalan, grafemik, pungtuasi, dan silabisasi. Kesalahan morfologi yang berhubungan dengan kesalahan dalam pembentukan kata. Kesalahan sintaksis yang berhubungan dengan kesalahan dalam bidang tata kalimat yang menyangkut urutan kata, susunan frasa, kepaduan, dan logika kalimat. Kesalahan semantik yang berhubungan dengan kesalahan dalam penggunaan kata, frasa, dan kalimat yang didukung oleh makna, baik makna gramatikal maupun makna leksikal.

Seperti yang telah disebutkan di atas, analisis kesalahan tata bahasa meliputi tataran fonologi, morfologi, sintaksis, dan semantik. Analisis kesalahan tata bahasa ini sangat luas cakupannya. Oleh karena itu, peneliti akan menganalisis kesalahan tata bahasa terbatas pada kesalahan sintaksis. Kesalahan sintaksis yang dianalisis adalah kesalahan sintaksis yang ditemukan pada karangan eksposisi siswa.

Kesalahan sintaksis ialah kesalahan yang berhubungan dengan bidang tata kalimat yang menyangkut urutan kata, susunan frasa, klausa, kepaduan, dan logika kalimat. Kesalahan sintaksis berhubungan dengan kalimat yang berstruktur tidak baku, kalimat 
yang ambigu, kalimat yang tidak tepat dalam pilihan kata atau diksi, kontaminasi atau kerancuan kalimat, kalimat mubazir atau pleonasme, ketidaktepatan bentuk kata, dan logika kalimat atau kesalahan logika.

Sebagai pengguna bahasa, kita diharapkan mampu menguasai berbagai keterampilan dalam menggunakan bahasa, khususnya bahasa Indonesia. Keterampilan dalam menggunakan bahasa disebut keterampilan berbahasa. Salah satu aspek keterampilan berbahasa adalah keterampilan atau kemampuan menulis. Kemampuan menulis adalah kemampuan melahirkan pikiran atau perasaan dalam bentuk bahasa tulisan.

Menurut Rosidi (2009:2), menulis adalah kegiatan untuk menyatakan pikiran dan perasaan dalam bentuk tulisan yang diharapkan dapat dipahami oleh pembaca dan berfungsi sebagai alat untuk berkomunikasi secara tidak langsung. Dengan kata lain, menulis merupakan kegiatan seseorang untuk menyampaikan gagasan dan perasaannya kepada pembaca dengan bahasa tulisan agas bisa dipahami oleh pembaca.

Penulis harus memahami sistem penulisan, struktrur bahasa, dan penguasaan kosakata serta memiliki pengetahuan yang baik mengenai sesuatu yang akan ditulisnya. Penulis juga harus memperhatikan kemampuan dan kebutuhan pembacanya. Dengan demikian, pembaca diharapkan dapat memahami pesan yang disampaikan oleh penulis.

Berdasarkan pendapat di atas, dapat disimpulkan bahwa menulis adalah suatu keterampilan berbahasa. Menulis merupakan kegiatan untuk menuangkan gagasan dan perasaan seseorang secara logis dan sistematis yang diungkapkan dalam bahasa tulisan. Tulisan yang dibuat penulis dapat dijadikan sarana untuk berkomunikasi antara penulis dengan pembaca meskipun secara tidak langsung atau tidak secara tatap muka.

\section{Karangan Eksposisi}

Kata eksposisi yang dipungut dari kata bahasa Inggris exposition sebenarnya berasal dari kata bahasa Latin yang berarti membuka atau memulai. Memang karangan eksposisi merupakan karangan yang bertujuan untuk memberi tahu, mengupas, menguraikan, atau menerangkan sesuatu. (Finoza, 2009: 246)

Menurut Sumarlam (2003 : 21), definisi karangan eksposisi adalah sebagai berikut:

"Karangan eksposisi adalah rangkaian tuturan yang bersifat memaparkan suatu pokok pikiran. Pokok pikiran itu lebih dijelaskan lagi dengan cara menyampaikan uraian bagian-bagian atau detailnya. Tujuan pokok dari karangan eksposisi adalah tercapainya tingkat pemahaman terhadap sesuatu secara lebih jelas, mendalam, dan luas daripada sekedar sebuah pertanyaan yang bersifat umum atau global. Kadang-kadang karangan ini dapat berbentuk ilustrasi dengan contoh, perbandingan, dan penentuan identifikasi dengan orientasi pokok pada masalah, bukan pada tokohnya".

Setiap jenis karangan, baik karangan narasi, deskripsi, argumentasi, eksposisi, maupun persuasi memiliki ciri-ciri yang berbeda satu dengan lainnya. Demikian pula dengan karangan eksposisi atau paparan yang memiliki ciri-ciri sebagai berikut:

1. Berusaha menjelaskan, menerangkan, atau memaparkan suatu persoalan tanpa usaha mempengaruhi pembaca 
2. Pembaca memutuskan sendiri untuk menerima atau tidak apa yang disampaikan penulis.

3. Dalam penyajiannya menggunakan gaya informatif, yang berusaha untuk menguraikan objek dengan sejelas jelasnya sehingga pembaca dapat menangkap informasinya dengan mudah.

4. Gaya bahasa yang digunakan adalah bahasa berita tanpa rasa subjektif dan emosional.

5. Fakta yang disajikan dipakai sebagai alat konkritisasi, yaitu membuat rumusan, kaidah, atau kesimpulan yang dikemukakan menjadi lebih konkret.

6. Berusaha untuk memperluas pandangan dan pengetahuan seseorang mengenai objek yang dibahas.

Karangan eksposisi bertujuan untuk memaparkan, menginformasikan, menjelaskan, memberitahu, mengupas, menguraikan, atau menerangkan sesuatu. Tujuan karangan eksposisi semata-mata untuk membagikan informasi dan sama sekali tidak untuk mendesak atau memaksa pembaca. Karangan eksposisi tidak akan mempengaruhi pembaca untuk menerima pandangan atau pendirian tertentu sebagai sesuatu yang benar.

Eksposisi atau paparan menyajikan fakta atau gagasan yang disusun dengan sebaik-baiknya sehingga mudah dipahami oleh pembaca. Oleh karena itu, paparan harus disusun secara teratur, logis, dan lengkap. Karangan eksposisi atau paparan dapat memaparkan ide, gagasan, atau pendapat secara panjang lebar atau bisa secara singkat. Karangan eksposisi dapat juga berisi konsep-konsep, logika, dan menerangkan proses serta prosedur suatu aktivitas.

Karangan eksposisi sangat tepat digunakan untuk menyampaikan uraian- uraian ilmiah populer atau uraian-uraian ilmiah lainnya yang tidak bertujuan untuk mempengaruhi pembacanya. Sesuatu yang diinformasikan dalam karangan eksposisi dapat berupa data faktual, yaitu suatu kondisi yang benarbenar terjadi, ada, dan dapat bersifat historis; suatu analisis atau penafsiran objektif terhadap seperangkat fakta; atau fakta tentang seseorang yang berpegang teguh pada suatu pendirian.

\section{Hakikat Analisis Kesalahan Berbahasa}

Salah satu pekerjaan guru adalah menilai kompetensi peserta didik. Pada waktu guru mengadakan penilaian pasti menemukan kesalahan. Kesalahan tersebut dianalisis dengan cara mengategorisasikannya, menentukan jenis, sifat, dan daerah kesalahannya. Kegiatan guru seperti itu disebut analisis kesalahan.

Dengan melakukan analisis kesalahan, guru dapat mengetahui langkah-langkah perbaikan dalam proses belajar mengajar berikutnya. Dengan demikian, kegiatan pembelajaran makin lama akan semakin membaik dan memperoleh hasil yang memuaskan.

Objek analisis kesalahan adalah bahasa. Oleh karena itu, analisis yang akan disampaikan adalah analisis kesalahan berbahasa. Analisis kesalahan berbahasa ini menitikberatkan pada analisis kesalahan bahasa ragam formal yaitu ragam bahasa yang digunakan dalam situasi resmi, misalnya pada saat proses belajar mengajar.

Analisis kesalahan berbahasa ditekankan pada proses belajar bahasa kedua (B2), termasuk bahasa asing. Dengan demikian objek analisis kesalahan adalah bahasa siswa yang sedang mempelajari bahasa kedua (B2) atau bahasa asing. Di Indonesia yang dimaksud bahasa kedua (B2), salah 
satunya adalah bahasa Indonesia yang dipelajari siswa di sekolah.

Kesalahan berbahasa adalah penyimpangan-penyimpangan yang bersifat sistematis yang dilakukan siswa ketika menggunakan bahasa. Kesalahan sistematis berhubungan dengan kompetensi. Berdasarkan pengertian tersebut, dapat dikatakan bahwa analisis kesalahan berbahasa adalah kegiatan menganalisis penyimpangan kompetensi kebahasaan siswa.

Menurut Tarigan (2011: 57), pengertian analisis kesalahan berbahasa sebagai berikut:

"Analisis kesalahan berbahasa adalah suatu proses kerja yang digunakan oleh para guru dan peneliti bahasa dengan langkahlangkah pengumpulan data, pengidentifikasian kesalahan yang terdapat di dalam data, penjelasan kesalahan tersebut, pengklasifikasian kesalahan itu berdasarkan penyebabnya, serta pengevaluasian taraf keseriusan kesalahan itu ".

Berdasarkan uraian di atas dapat disimpulkan bahwa kesalahan berbahasa adalah penyimpangan yang dilakukan siswa dalam kegiatan berbahasanya. Sementara itu, analisis kesalahan berbahasa adalah proses mendata kesalahan yang ditemui, mengidentifikasi jenis kesalahan, mengklasifikasi sifat kesalahan, dan menentukan sumber serta penyebab penyimpangan atau kesalahan berbahasa yang dilakukan siswa.

\section{Hakikat Sintaksis}

Menurut Tarigan (2009:4), sintaksis adalah salah satu cabang tata bahasa yang menelaah struktur-struktur kalimat, klausa, dan frasa.

Menurut Achmad (2008:1), sintaksis sebagai subsistem bahasa, mempersoalkan hubungan antara kata dan satuan lain yang lebih besar dan membentuk suatu konstruksi yang disebut kalimat. Dalam studi sintaksis yang lebih luas dan mendalam, dibicarakan mengenai alat-alat sintaksis dan satuan-satuan sintaksis. Alat-alat sintaksis terdiri atas urutan, bentuk kata, intonasi, dan partikel atau kata tugas. Satuan-satuan sintaksis terdiri atas kata, frasa, klausa, dan kalimat.

Berdasarkan pendapat di atas dapat disimpulkan bahwa sintaksis adalah cabang tata bahasa yang mempelajari atau menelaah seluk-beluk kalimat. Kalimat dapat berbentuk kata, frasa, atau klausa.

Kalimat adalah satuan bahasa yang secara relatif dapat berdiri sendiri yang mempunyai pola intonasi akhir dan yang terdiri dari klausa (Cook, 1971:39-40; Elson dan Pickett, 1969:82 dalam Tarigan, 2009:6)

Definisi kalimat menurut Achmad (2008:112), sebagai berikut:

"Kalimat merupakan satuan di bawah tataran wacana. Wacana dibentuk oleh kalimat-kalimat. Perilaku kalimat sebagai unsur pembentuk wacana sangat beragam. Ada yang secara potensial dapat berdiri sendiri, namun ada juga yang memiliki ketergantungan dengan kalimat yang lain. Ada kalanya kalimat dibentuk oleh kata, atau frasa, atau dapat juga oleh klausa"

Menurut Achmad (2008:112), dalam pandangan gramatikal, kalimat merupakan salah satu satuan yang tetap terikat pada satuan yang lebih besar atau dapat berdiri sendiri, mempunyai pola intonasi final, terdiri dari klausa. Dalam kaitannya dengan satuan-satuan sintaksis (kata, frasa, klausa), kalimat dapat dipandang sebagai suatu konstruksi yang disusun dari konstituen dasar yang biasanya berupa klausa 
disertai intonasi final dan bila perlu dilengkapi konjungsi.

Definisi lain tentang kalimat disampaikan oleh E. Zaenal Arifin, S. Amran Tasai (2009: 66) sebagai berikut: "Kalimat adalah satuan bahasa terkecil, dalam wujud lisan dan tulisan, yang mengungkapkan pikiran yang utuh. Dalam wujud lisan, kalimat diucapkan dengan suara naik turun, dan keras lembut, disela jeda, dan diakhiri dengan intonasi akhir. Dalam bentuk tulisan berhuruf latin kalimat dimulai dengan huruf kapital dan diakhiri dengan tanda titik (.), tanda tanya (?), atau tanda seru (!)".

Menurut Tarigan (2009:6), kalimat dapat diklasifikasikan dengan berbagai cara, antara lain berdasarkan jumlah dan jenis klausa, struktur internal klausa utama, jenis responsi yang diharapkan, sifat hubungan aktor-aksi, ada atau tidaknya unsur negatif pada frasa verbal utama, kesederhanaan dan kelengkapan dasar, posisinya dalam percakapan, dan konteks dan jawaban yang diberikan.

Menurut Achmad (2008:115), kalimat dapat diklasifikasikan dengan menggunakan berbagai kriteria atau tinjauan, antara lain berdasarkan jumlah klausa, struktur klausa, amanat wacana, pembentukan kalimat dari klausa inti dan perubahannya, jenis klausa, dan fungsi kalimat sebagai pembentuk paragraf. Klasifikasi kalimat tersebut diuraikan sebagai berikut:

1. Berdasarkan jumlah klausa, kalimat dibedakan menjadi kalimat tunggal, kalimat bersusun, dan kalimat majemuk.

a. Kalimat tunggal adalah kalimat yang terdiri dari satu klausa bebas tanpa klausa terikat. Kalimat tunggal disebut juga kalimat sederhana atau kalimat simpleks, atau kalimat ekaklausa.
Contoh : Dia datang dari Jakarta. ( S-P-K)

b. Kalimat bersusun adalah kalimat yang terdiri dari satu klausa bebas dan sekurang-kurangnya satu klausa terikat. Kalimat bersusun disebut juga kalimat majemuk bertingkat atau kalimat majemuk subordinatif. Contoh : Dia tidak mencuci mobil karena hari hujan.

c. Kalimat majemuk adalah kalimat yang terdiri dari beberapa klausa bebas. Kalimat majemuk disebut juga kalimat setara. Klausaklausa yang menbentuk kalimat ini memiliki status sama, setara, sederajat, dan berhubungan secara koordinatif. Contoh : Dia datang dan duduk di sebelah saya.

2. Berdasarkan struktur klausa, kalimat dibedakan menjadi kalimat lengkap dan kalimat tak lengkap.

a. Kalimat lengkap adalah kalimat yang mengandung klausa lengkap. Kelengkapan suatu klausa ditentukan sekurangkurangnya oleh unsur subjek dan predikat. Kalimat lengkap disebut juga kalimat mayor atau kalimat berklausa. Contoh: Negara Indonesia berdasarkan Pancasila.

b. Kalimat tak lengkap adalah kalimat yang terdiri dari klausa yang tidak lengkap, yaitu yang terdiri dari subjek saja, predikat saja, objek saja, atau keterangan saja. Kalimat tak lengkap disebut juga kalimat minor atau kalimat tak berklausa. Kalimat tak lengkap ada beberapa jenis yaitu kalimat elips, kalimat sampingan, kalimat urutan, dan kalimat minor. Contoh: Astaga!; Dari toko; Ali; Selamat malam! 
3. Berdasarkan amanat wacana, kalimat dibedakan menjadi kalimat deklaratif, kalimat interogatif, kalimat imperatif, kalimat aditif, kalimat responsif, dan kalimat interjeksi.

a. Kalimat deklaratif adalah kalimat yang mengandung intonasi deklaratif (berita), yang dalam ragam tulis diberi atau diakhiri dengan tanda titik (.). Contoh: Gaji pegawai negeri belum dinaikkan.

b. Kalimat interogatif adalah kalimat yang mengandung intonasi interogatif (pertanyaan), yang dalam ragam tulis diberi atau diakhiri dengan tanda tanya (?). Contoh : Bagaiman cara menggunakan alat ini?

c. Kalimat imperatif adalah kalimat yang mengandung intonasi imperatif (perintah), yang dalam ragam tulis diberi atau diakhiri dengan tanda seru (!). Contoh: Bacalah buku itu!

d. Kalimat aditif adalah kalimat terikat yang bersambung dengan kalimat pernyataan, bisa lengkap, bisa juga tidak. Contoh: Cuma belum punya anak.

e. Kalimat responsif adalah kalimat terikat yang bersambung dengan kalimat pertanyaan, bisa lengkap, bisa juga tidak. Contoh: Tadi pagi!

f. Kalimat interjektif adalah kalimat yang dapat terikat atau tidak dengan kalimat seruan. Contoh: Wah, ini baru kejutan!; Mudah-mudahan Tuhan selalu menyertaimu!

4. Berdasarkan pembentukan kalimat dari klausa inti dan perubahannya, kalimat dibedakan menjadi kalimat inti dan kalimat noninti (bukan inti).

a. Kalimat inti adalah kalimat yang dibentuk dari klausa inti yang lengkap, bersifat deklaratif, aktif, netral, atau afirmatif. Kalimat inti disebut juga kalimat dasar.

b. Kalimat noninti adalah kalimat hasil tranformasi dari kalimat inti. Proses transformasi dapat berupa pemasifan, pengingkaran, penanyaan, perintahan, penginversian, pelesapan, dan penambahan.

5. Berdasarkan jenis klausa, kalimat dibedakan menjadi kalimat verbal dan kalimat nonverbal

a. Kalimat verbal adalah kalimat yang dibentuk dari klausa verbal atau kalimat yang konstituen dasarnya adalah klausa verbal. Klausa verbal dapat berupa verbal transitif, intransitif, atau pasif.

b. Kalimat nonverbal adalah kalimat yang dibentuk oleh klausa nonverbal. Klausa nonverbal mencakup antara lain klausa nominal, klausa ajektifal, klausa numeralia, klausa preposisional, klausa pronominal, dan lain-lain.

6. Berdasarkan fungsi kalimat sebagai pembentuk paragraf, kalimat dibedakan menjadi kalimat bebas dan kalimat terikat.

a. Kalimat bebas adalah kalimat yang mempunyai potensi untuk menjadi ujaran lengkap tanpa konteks lain yang memberi penjelasan.

b. Kalimat terikat adalah kalimat yang tidak dapat berdiri sendiri sebagai ujaran lengkap. Kalimat terikat biasanya menggunakan tanda keterkaitan seperti pananda perangkai, penanda penunjuk, atau penanda anafora.

Mengenai kalimat efektif perlu disampaikan karena kesalahan yang terjadi pada tataran sintaksis ditandai dengan ketidakefektifan kalimat yang 
digunakan, terutama pada pemakaian bahasa ragam tulis.

Menurut E. Zaenal Arifin dan S. Amran Tasai (2009, 97), kalimat efektif adalah kalimat yang memiliki kemampuan untuk menimbulkan kembali gagasan-gagasan pada pikiran pendengar atau pembaca seperti apa yang ada dalam pikiran pembicara atau penulis.

Menurut J.S. Badudu dalam Putrayasa (2007:1), kalimat efektif ialah kalimat yang baik karena apa yang dipikirkan atau dirasakan oleh si pembicara atau si penulis dapat diterima dan dipahami oleh pendengar atau pembaca sama benar dengan apa yang dipikirkan atau dirasakan si penutur atau si penulis.

Menurut Putrayasa (2007:47), kalimat dikatakan efektif jika memenuhi dua syarat utama yaitu struktur kalimat efektif dan ciri kalimat efektif. Struktur kalimat efektif mencakup kalimat umum, kalimat paralel, dan kalimat periodik. Ciri kalimat efektif mencakup kesatuan (unity), kehematan (economy), penekanan (emphasis), dan kevariasian (variety).

Menurut E. Zaenal Arifin dan S. Amran Tasai (2009, 97), sebuah kalimat efektif mempunyai ciri-ciri khas, yaitu kesepadanan struktur, keparalelan bentuk, ketegasan makna, kehematan kata, kecermatan penalaran, kepaduan gagasan, dan kelogisan bahasa.

Jadi, kalimat efektif adalah kalimat yang dapat mengungkapkan gagasan, pikiran, dan perasaan dengan tepat ditinjau dari segi diksi, struktur, dan logikanya. Kalimat efektif mampu membuat proses penyampaian dan penerimaan berlangsung dengan sempurna. Kalimat efektif selalu berterima secara tata bahasa dan makna. Sebuah kalimat dikatakan efektif apabila mencapai sasarannya dengan baik sebagai alat komunikasi.
Sintaksis adalah cabang tata bahasa yang mempelajari atau menelaah seluk-beluk kalimat. Kalimat adalah suatu satuan bahasa berupa kata, frasa, atau klausa yang dapat berdiri sendiri dan mempunyai pola intonasi final. Oleh karena itu, kesalahan sintaksis adalah kesalahan yang berhubungan dengan kalimat. Semua kesalahan sintaksis tersebut dapat menimbulkan ketidakefektifan sebuah kalimat.

Menurut Putrayasa (2007:95), ketidakefektifan kalimat disebabkan oleh beberapa faktor. Faktor-faktor tersebut meliputi kontaminasi atau kerancuan, pleonasme, ambiguitas atau keambiguan, ketidakjelasan subjek atau unsur inti, kemubaziran preposisi dan kata, kesalahan logika atau nalar, ketidaktepatan bentuk kata, ketidaktepatan makna kata, pengaruh bahasa daerah, dan pengaruh bahasa asing.

Jenis-jenis kesalahan sintaksis tersebut diuraikan sebagai berikut:

1. Kalimat yang berstruktur tidak baku Kalimat yang berstruktur tidak baku ialah kalimat yang strukturnya tidak sesuai dengan unsur-unsur yang membangun kalimat. Unsur yang membangun kalimat dapat dibedakan menjadi dua, yaitu unsur wajib dan unsur manasuka (Putrayasa, 2007 : 47). Unsur wajib adalah unsur yang harus ada dalam sebuah kalimat yaitu subjek (S) dan predikat (P). Jika predikat sebuah kalimat berupa kata kerja transitif, unsur kalimat yang disebut objek (O) juga harus hadir. Unsur manasuka adalah unsur yang boleh ada dan boleh tidak ada dalam sebuah kalimat yaitu kata kerja bantu, keterangan aspek, keterangan tempat, keterangan waktu, dan sebagainya. 
2. Kalimat yang ambigu

Kalimat yang ambigu ialah kalimat yang masih menimbulkan tafsiran ganda meskipun kalimat tersebut sudah memenuhi ketentuan tata bahasa.

3. Kalimat yang tidak tepat dalam pilihan kata/diksi

Kalimat yang tidak tepat dalam pilihan kata/diksi ialah pilihan kata yang tidak tepat untuk menunjukkan maksud yang dikehendaki penulis dalam sebuah kalimat sehingga menimbulkan keganjilan, kekaburan, dan salah tafsir.

4. Kontaminasi atau kerancuan kalimat Kontaminasi atau kerancuan kalimat ialah kalimat yang susunannya tidak teratur sehingga informasinya sulit dipahami. Pada umumnya kerancuan sebuah kalimat disebabkan karena dua gagasan digabungkan ke dalam satu pengungkapan atau penggabungan dua struktur kalimat ke dalam satu struktur.

5. Kalimat mubazir atau pleonasme

$$
\text { Kalimat mubazir atau }
$$

pleonasme ialah pemakaian katakata yang berlebihan. Penampilannya bermacam-macam. Ada penggunaan dua kata yang searti, ada penggunaan kata yang tidak perlu karena pengertiannya sudah terkandung pada kata yang mendahuluinya, dan ada penggunaan bentuk jamak yang dinyatakan dua kali.

6. Ketidaktepatan bentuk kata

Ketidaktepatan bentuk kata ialah penggunaan bentuk-bentuk kata yang kurang tepat dalam kalimat, misalnya bentuk kata berimbuhan, kata majemuk, kata ulang, dan bentuk-bentuk kata tidak baku.
7. Logika kalimat/kesalahan nalar Logika kalimat/kesalahan nalar ialah kalimat yang tidak dapat diterima atau dipahami oleh pikiran pembaca atau pendengar atau kalimat yang tidak menunjukkan hubungan makna yang logis.

\section{METODE PENELITIAN}

Penelitian ini menggunakan pendekatan kualitatif. Pendekatan kualitatif ialah penelitian yang menghasilkan prosedur analisis yang tidak menggunakan prosedur analisis statistik atau cara kualifikasi yang lainnya. Penelitian kualitatif mengedepankan kedalaman penghayatan terhadap interaksi antarkonsep yang sedang dikaji secara empiris dengan menggunakan kata-kata atau gambar. Dalam penelitian kualitatif yang lebih ditekankan adalah persoalan kedalaman (kualitas) data bukan banyaknya (kuantitas) data (Hariwijaya, 2007:71).

Penelitian dengan pendekatan kualitatif ini menggunakan metode analisis isi (content analysis). Analisis isi (content analysis) ini digunakan dalam pencarian fakta dengan interpretasi data suatu karangan. Maksudnya, dengan penelitian terhadap karangan, peneliti membaca karangan dan menganalisis isi karangan tersebut. Analisis yang dilakukan adalah analisis terhadap kesalahan pada tataran sintaksis yang terdapat dalam karangan eksposisi siswa kelas XI SMA Bina Spora Mandiri Cigombong Bogor.

Dalam penelitian ini, peneliti menggunakan teknik kualitatif deskriptif. Penelitian deskriptif menjelaskan fenomena dengan aturan berpikir ilmiah yang diterapkan secara sistematis. Penelitian deskriptif merupakan pengumpulan dan penyusunan data, serta analisis dan 
penafsiran data tersebut. Data yang dikumpulkan dan dianalisis berupa katakata dan kalimat.

Teknik penelitian deskriptif yang dilakukan peneliti adalah teknik meneliti isi karangan eksposisi dengan memperhatikan setiap kata dan kalimat kemudian menganalisis kesalahannya. Teknik penelitian ini dapat dilakukan dengan membaca karangan eksposisi siswa, mengidentifikasi, mengklasifikasi, menganalisis, dan menyimpulkan kesalahan kata dan kalimat yang terdapat dalam karangan tersebut.

\section{Subjek dan Fokus Penelitian}

1. Subjek Penelitian

Subjek penelitian adalah data yang akan diteliti atau dianalisis. Dalam penelitian ini, yang akan dijadikan subjek penelitian adalah karangan eksposisi siswa kelas XI SMA Bina Spora Mandiri Cigombong Bogor. Karangan siswa yang akan diteliti atau dianalisis berjumlah 31 karangan.

2. Fokus Penelitian

Fokus penelitian yang dilakukan terhadap karangan eksposisi siswa adalah meneliti dan menganalisis karangan siswa tersebut berdasarkan kesalahan sintaksis yang sesuai dengan teoriatau aturan tata bahasa yang berlaku.

\section{Instrumen Penelitian}

Dalam penelitian kualitatif, yang menjadi instrumen atau alat penelitian adalah peneliti itu sendiri (Sugiyono, 2010:222). Peneliti kualitatif sebagai human instrument, berfungsi menetapkan fokus penelitian, memilih informan sebagai sumber data, melakukan pengumpulan data, menilai kualitas data, analisis data, menafsirkan data, dan membuat simpulan atas temuannya. Dalam penelitian ini, peneliti menggunakan sumber data yang akan dipergunakan sebagai alat bantu penelitian, yaitu:

1. Karangan eksposisi siswa yang berjumlah 31 buah

2. Tabel analisis

Penggunaan tabel analisis bertujuan untuk mengumpulkan dan mengolah data-data sehingga dapat mempermudah peneliti dalam menganalisis serta menginterpretasikan data yang terkumpul berupa kata-kata yang penggunaannya salah dan pemakaian kalimat yang tidak tepat sesuai kaidah tata bahasa yang berlaku. Tabel analisis yang dipergunakan adalah sebagai berikut.

c. Tabel Analisis Jenis Kesalahan Sintaksis

\begin{tabular}{|c|c|c|c|c|c|c|c|c|}
\hline \multirow[t]{2}{*}{ No. } & \multirow[t]{2}{*}{ Judul Karangan dan Kalimat } & \multicolumn{7}{|c|}{ Tipe-Tipe Kesalahan Sintaksis } \\
\hline & & 1 & 2 & 3 & 4 & 5 & 6 & 7 \\
\hline 1. & & & & & & & & \\
\hline 2. & & & & & & & & \\
\hline 3. & & & & & & & & \\
\hline 4. & & & & & & & & \\
\hline dst & & & & & & & & \\
\hline
\end{tabular}

Sumber: Putrayasa (2007:95)

Keterangan :

1. kalimat yang berstruktur tidak baku

2. kalimat yang ambigu

3. kalimat yang tidak tepat dalam pilihan kata/diksi

4. kontaminasi atau kerancuan kalimat 
5. kalimat mubazir atau pleonasme

6. ketidaktepatan bentuk kata

7. logika kalimat atau kesalahan nalar

\section{Teknik Analisis Data}

Teknik analisis data yang dipergunakan dalam penelitian ini dilakukan secara deskriptif dengan analisis isi yaitu dengan menginterpretasikan setiap kata dan kalimat yang mengalami kesalahan dengan teori atau aturan yang berlaku. Teknik analisis data tersebut dapat dideskripsikan dengan langkah-langkah, sebagai berikut:

1. Membaca dengan cermat data yang dianalisis berupa karangan eksposisi siswa

2. Mengidentifikasi kata-kata dan kalimat yang dianggap salah

3. Memasukkan kata-kata dan kalimat yang salah ke dalam tabel

4. Mengklasifikasi kesalahan kata-kata dan kalimat tersebut berdasarkan jenisnya dan sumber kesalahannya

5. Menganalisis dan menyimpulkan kesalahan-kesalahan yang ditemukan dalam karangan eksposisi siswa

\section{Kriteria Analisis}

Kriteria yang digunakan untuk menganalisis data dalam penelitian ini meliputi:

Kriteria analisis jenis ke salahan sintaksis, terdiri atas:

1. Kalimat yang berstruktur tidak baku

\begin{tabular}{|lr|lr|}
\hline \multicolumn{2}{|c|}{ Kalimat yang } & \multicolumn{2}{c|}{ Seharusnya } \\
\hline Bagi para & Para mahasiswa \\
mahasiswa yang & yang akan \\
akan mengikuti & mengikuti ujian \\
ujian harus & harus melunasi \\
melunasi uang & uang SPP \\
SPP & \multicolumn{2}{|c|}{} \\
\hline
\end{tabular}

2. Kalimat yang ambigu

\begin{tabular}{|c|c|}
\hline $\begin{array}{l}\text { Kalimat yang } \\
\text { salah }\end{array}$ & Seharusnya \\
\hline $\begin{array}{ll}\text { Tahun ini } & \text { SPP } \\
\text { mahasiswa } & \text { baru } \\
\text { dinaikkan } & \end{array}$ & $\begin{array}{l}\text { Tahun ini SPP } \\
\text { mahasiswa-baru } \\
\text { dinaikkan } \\
\text { - SPP mahasiswa } \\
\text { tahun ini baru } \\
\text { dinaikkan }\end{array}$ \\
\hline
\end{tabular}

3. Kalimat yang tidak tepat dalam pilihan kata/diksi

\begin{tabular}{|l|l|}
\hline \multicolumn{1}{|c|}{$\begin{array}{c}\text { Kalimat yang } \\
\text { salah }\end{array}$} & \multicolumn{1}{c|}{ Seharusnya } \\
\hline $\begin{array}{l}\text { Aduh, kepala saya } \\
\text { bingung }\end{array}$ & $\begin{array}{l}\text { Aduh, kepala saya } \\
\text { pusing }\end{array}$ \\
\hline
\end{tabular}

4. Kalimat yang rancu atau kontaminasi

\begin{tabular}{|c|c|}
\hline $\begin{array}{c}\text { Kalimat yang } \\
\text { salah }\end{array}$ & Seharusnya \\
\hline $\begin{array}{l}\text { Dalam pertemuan } \\
\text { itu membicarakan } \\
\text { pascaperang } \\
\text { Teluk }\end{array}$ & $\begin{array}{l}\text { - Pertemuan itu } \\
\text { membicarakan } \\
\text { pascaperang } \\
\text { Teluk }\end{array}$ \\
\hline & $\begin{array}{l}\text { - Dalam } \\
\text { pertemuan itu } \\
\text { dibicarakan } \\
\text { pascaperang } \\
\text { Teluk }\end{array}$ \\
\hline
\end{tabular}

5. Kalimat mubazir atau pleonasme

\begin{tabular}{|l|l|}
\hline \multicolumn{1}{|c|}{$\begin{array}{c}\text { Kalimat yang } \\
\text { salah }\end{array}$} & \multicolumn{1}{c|}{ Seharusnya } \\
\hline $\begin{array}{l}\text { Para guru-guru } \\
\text { sedang rapat }\end{array}$ & $\begin{array}{l}\text { Para guru sedang } \\
\text { rapat }\end{array}$ \\
\hline
\end{tabular}

6. Ketidaktepatan bentuk kata

\begin{tabular}{|c|c|}
\hline $\begin{array}{c}\text { Kalimat yang } \\
\text { salah }\end{array}$ & Seharusnya \\
\hline $\begin{array}{l}\text { Pendidikan dapat } \\
\text { merubah } \\
\text { kepribadian } \\
\text { seseorang }\end{array}$ & $\begin{array}{l}\text { Pendidikan dapat } \\
\text { mengubah } \\
\text { kepribadian } \\
\text { seseorang }\end{array}$ \\
\hline
\end{tabular}


7. Logika kalimat atau kesalahan nalar

\begin{tabular}{|c|c|}
\hline $\begin{array}{l}\text { Kalimat yang } \\
\text { salah }\end{array}$ & Seharusnya \\
\hline $\begin{array}{lr}\text { Juara } & \text { kedua } \\
\text { diduduki } & \text { Widi } \\
\text { dari Jakarta } & \end{array}$ & 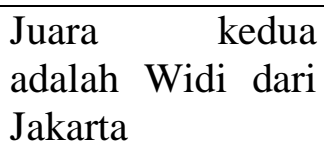 \\
\hline
\end{tabular}

\section{HASIL DAN PEMBAHASAN}

\section{DESKRIPSI PENELITIAN \\ INFORMASI}

Deskripsi informasi penelitian adalah gambaran mengenai data yang diteliti. Data yang diteliti yaitu 31 buah karangan eksposisi siswa kelas XI SMA Bina Spora Mandiri Cigombong, Bogor. Karangan tersebut diteliti berdasarkan kesalahan sintaksisnya. Dari ketiga puluh satu karangan yang diteliti diperoleh hasil sebanyak 92 kesalahan sintaksis dan diteliti berdasarkan jenis kesalahannya.

Jenis kesalahan sintaksis terdiri atas kalimat yang berstruktur tidak baku, kalimat yang ambigu, kalimat yang tidak tepat dalam pilihan kata/diksi, kontaminasi atau kerancuan kalimat, kalimat mubazir atau pleonasme, ketidaktepatan bentuk kata, dan logika kalimat atau kesalahan nalar.

\section{DESKRIPSI JENIS KESALAHAN SINTAKSIS SELURUH KARANGAN}

Deskripsi jenis kesalahan sintaksis seluruh karangan merupakan rekapitulasi data kesalahan sintaksis yang terdapat pada karangan eksposisi siswa kelas XI SMA Bina Spora Mandiri yang berjumlah 31 karangan. Dari 31 karangan yang diteliti dan dianalisis, diperoleh 92 kalimat dengan 263 kesalahan sintaksis. Hal ini terjadi karena sebagian besar kalimat yang dianalisis mengalami lebih dari satu kesalahan.

Jenis-jenis kesalahan sintaksis yang terdapat pada karangan eksposisi siswa kelas XI SMA Bina Spora Mandiri tersebut terdiri atas kalimat yang strukturnya tidak baku, kalimat yang ambigu, kalimat yang tidak tepat dalam pilihan kata/diksi, kontaminasi atau kerancuan kalimat, kalimat mubazir atau pleonasme, ketidaktepatan bentuk kata, dan logika kalimat atau kesalahan nalar. Deskripsi jenis kesalahan sintaksis seluruh karangan dapat dilihat pada tabel berikut.

Tabel Jenis Kesalahan Sintaksis Seluruh Karangan

\begin{tabular}{|c|c|c|c|}
\hline No. & $\begin{array}{c}\text { Jenis Kesalahan } \\
\text { Sintaksis }\end{array}$ & $\begin{array}{l}\text { Jum- } \\
\text { lah }\end{array}$ & Persentase \\
\hline 1 & $\begin{array}{ll}\text { Kalimat } & \text { yang } \\
\text { bestruktur } & \text { tidak } \\
\text { baku } & \end{array}$ & 62 & $23,57 \%$ \\
\hline 2 & $\begin{array}{l}\text { Kalimat } \\
\text { ambigu }\end{array}$ & 1 & $0,38 \%$ \\
\hline 3 & $\begin{array}{l}\text { Kalimat yang tidak } \\
\text { tepat dalam pilihan } \\
\text { kata/diksi }\end{array}$ & 64 & $24,33 \%$ \\
\hline 4 & $\begin{array}{l}\text { Kontaminasi atau } \\
\text { kerancuan kalimat }\end{array}$ & 16 & $6,08 \%$ \\
\hline 5 & $\begin{array}{l}\text { Kalimat mubazir } \\
\text { atau pleonasme }\end{array}$ & 44 & $16,73 \%$ \\
\hline 6 & $\begin{array}{l}\text { Ketidaktepatan } \\
\text { bentuk kata }\end{array}$ & 53 & $20,15 \%$ \\
\hline 7 & $\begin{array}{l}\text { Logika kalimat atau } \\
\text { kesalahan nalar }\end{array}$ & 23 & $8,75 \%$ \\
\hline & Jumlah & 263 & $100,0 \%$ \\
\hline
\end{tabular}

\section{PEMBAHASAN DAN URAIAN PENELITIAN}

\section{Kesalahan Sintaksis}

Jenis Kesalahan Sintaksis

Dilihat dari jumlah kalimat yang mengalami kesalahan yaitu sebanyak 92 kalimat dengan 263 kesalahan, diperoleh data bahwa jenis kesalahan sintaksis yang muncul diurutkan sebagai berikut:

1. Kalimat yang tidak tepat dalam pilihan kata/diksi

Kalimat yang tidak tepat dalam pilihan kata/diksi ialah pilihan kata yang tidak tepat untuk menunjukkan 
maksud yang dikehendaki penulis dalam sebuah kalimat sehingga menimbulkan keganjilan, kekaburan, dan salah tafsir. Ada 64 kalimat atau $24,33 \%$ kalimat yang tidak tepat dalam pilihan kata/diksi.

2. Kalimat yang berstruktur tidak baku

Kalimat yang berstruktur tidak baku ialah kalimat yang strukturnya tidak sesuai dengan unsur-unsur yang membangun kalimat. Unsur yang membangun kalimat dapat dibedakan menjadi dua, yaitu unsur wajib dan unsur manasuka. Unsur wajib adalah unsur yang harus ada dalam sebuah kalimat yaitu subjek (S) dan predikat (P). Jika predikat sebuah kalimat berupa kata kerja transitif, unsur kalimat yang disebut objek (O) juga harus hadir. Unsur manasuka adalah unsur yang boleh ada dan boleh tidak ada dalam sebuah kalimat yaitu kata kerja bantu, keterangan aspek, keterangan tempat, keterangan waktu, dan sebagainya. Ada 62 kalimat atau $23,57 \%$ kalimat yang berstruktur tidak baku.

3. Ketidaktepatan bentuk kata

Ketidaktepatan bentuk kata ialah penggunaan bentuk-bentuk kata yang kurang tepat dalam kalimat, misalnya bentuk kata berimbuhan, kata ulang, kata majemuk, bentuk-bentuk kata tidak baku, dan penulisan kata depan. Ada 53 kalimat atau 20,16\% kalimat yang mengandung ketidaktepatan bentuk kata.

4. Kalimat mubazir atau pleonasme Kalimat mubazir atau pleonasme ialah pemakaian katakata yang berlebihan. Penampilannya bermacam-macam. Ada penggunaan dua kata yang searti, ada penggunaan kata yang tidak perlu karena pengertiannya sudah terkandung pada kata yang mendahuluinya, dan ada penggunaan bentuk jamak yang dinyatakan dua kali. Ada 44 kalimat atau 16,73\% kalimat mubazir atau pleonasme.

5. Logika kalimat atau kesalahan nalar

Logika kalimat atau kesalahan nalar ialah kalimat yang tidak dapat diterima atau dipahami oleh pikiran pembaca atau pendengar atau kalimat yang tidak menunjukkan hubungan makna yang logis. Hal ini juga dipengaruhi oleh pemilihan kata yang kurang tepat. Ada 23 kalimat atau $8,75 \%$ kalimat yang tidak memiliki logika kalimat atau kalimat yang mengalami kesalahan nalar.

6. Kontaminasi atau kerancuan kalimat

Kontaminasi atau kerancuan kalimat ialah kalimat yang susunannya tidak teratur sehingga informasinya sulit dipahami. Pada umumnya kerancuan sebuah kalimat disebabkan oleh dua gagasan yang digabungkan ke dalam satu pengungkapan atau penggabungan dua struktur kalimat ke dalam satu struktur. Ada 16 kalimat atau 6,08\% kalimat yang mengalami kontaminasi atau kerancuan kalimat.

7. Kalimat yang ambigu

Kalimat yang ambigu ialah kalimat yang masih menimbulkan tafsiran ganda meskipun kalimat tersebut sudah memenuhi ketentuan tata bahasa. Hal ini dipengaruhi oleh pemilihan kata yang kurang tepat. Ada 1 kalimat atau $0,38 \%$ kalimat yang ambigu.

Dengan memerhatikan tujuh kesalahan sintaksis di atas, siswa masih banyak yang belum memahami tata cara penulisan kalimat, mengorganisiasi kata menjadi kalimat yang padu, menggunakan bentuk baku yang sesuai dengan kaidah bahasa Indonesia, menggunakan kata atau kalimat yang efektif sehingga tidak mubazir, dan memilih atau menggunakan kata yang 
tepat sehingga terhindar dari makna kalimat yang ambigu dan kesalahan nalar.

\section{SIMPULAN}

Penelitian yang dilakukan terhadap 31 karangan eksposisi siswa kelas XI SMA Bina Spora Mandiri menghasilkan sejumlah data dan temuan tentang jenis dan sumber kesalahan sintaksis. Dari 31 karangan eksposisi siswa XI SMA Bina Spora Mandiri yang diteliti ditemukan sebanyak 92 kalimat mengalami kesalahan sintaksis.

Jenis kesalahan sintaksis yang ditemukan dalam karangan eksposisi siswa kelas XI SMA Bina Spora Mandiri, akan diuraikan secara berurutan dari yang pemunculannya paling banyak yaitu kalimat yang tidak tepat dalam pilihan kata/diksi sebanyak 64 kalimat atau $24,33 \%$, kalimat yang berstruktur tidak baku sebanyak 62 kalimat atau 23,57\%, kesalahan pada ketidaktepatan bentuk kata sebanyak 53 kalimat atau 20,15\%, kalimat mubazir atau pleonasme sebanyak 44 kalimat atau $16,73 \%, \%$, kalimat yang tidak memiliki logika atau mengalami kesalahan nalar sebanyak 23 kalimat atau $8,75 \%$, kontaminasi atau kerancuan kalimat sebanyak 16 kalimat atau 6,08\%, dan kalimat yang ambigu sebanyak 1 kalimat atau $0,38 \%$.

Berdasarkan hasil penelitian yang telah disampaikan dalam simpulan tentang jenis kesalahan sintaksis, berikut disampaikan saran-saran:

1. Bagi Peneliti Lain

Peneliti dalam penelitian ini memiliki keterbatasan waktu, ilmu, dan bidang penelitian, oleh karena itu diharapkan ada peneliti lain yang mengembangkan penelitian ini. Penelitian dapat dilakukan tidak terbatas pada bidang sintaksis saja, tetapi bisa meneliti bidang fonologi, morfologi, atau semantik. Tidak terbatas pada karangan eksposisi saja tetapi pada karya tulis, makalah, atau skripsi yang dibuat oleh mahasiswa.

2. Bagi Guru bahasa Indonesia.

Guru, khususnya guru bahasa Indonesia sebaiknya melakukan penelusuran kompetensi yang intensif sebelum memberikan materi pembelajaran. Dengan mengetahui kompetensi yang masih belum dikuasai siswa, proses pembelajaran akan lebih fokus, efektif, dan efisien serta memperoleh hasil pembelajaran yang memuaskan.

Hasil penelitian tentang jenis kesalahan sintaksis ini juga dapat dipergunakan untuk menentukan langkah-langkah dalam proses pembelajaran, menyusun materi pembelajaran secara bertahap dari yang mudah ke yang sukar, dari yang sederhana ke yang rumit, dari yang sempit ke yang luas, dan sebagainya.

Untuk pengajar bahasa Indonesia di SMA Bina Spora Mandiri, hasil penelitian ini dapat dipergunakan untuk mengetahui kemampuan kebahasaan khususnya bidang sintaksis yang dikuasai siswa SMA Bina Spora Mandiri yang ternyata masih kurang atau masih banyak melakukan kesalahan sehingga dalam setiap pembelajaran perlu disampaikan hal-hal yang berkaitan dengan bidang sintaksis atau tata kalimat.

\section{UCAPAN TERIMA KASIH}

Ucapan terima kasih penulis sampaikan kepada pimpinan Universitas Indraprasta PGRI yang telah memberi kesempatan, fasilitas, dan motivasi untuk berkarya. Tak lupa pihak sekolah sebagai objek data penelitian. Juga kepada ketua, sekretaris, dan anggota Lembaga Penelitian dan Pengabdian 
Masyarakat (LPPM) Universitas Indraprasta PGRI yang telah menyetujui artikel ini untuk dimuat di jurnal ilmiah dan mempublikasikan hasil penelitian ini.

\section{DAFTAR PUSTAKA}

Arifin, E. Z. dan S. Amran Tasai. (2009). Cermat Berbahasa Indonesia. Jakarta: Akademika Pressindo.

Depdiknas. (2013). Model Silabus dan Rencana Pelaksanaan Pembelajaran. Jakarta: Direktorat Jenderal Manajemen Pendidikan Dasar dan Menengah.

Finoza, L. (2009). Komposisi Bahasa Indonesia. Jakarta : Diksi Insan Mulia.

Hariwijaya, M. (2007). Metodologi dan Teknik Penulisan Skripsi, Tesis, dan Disertasi. Yogyakarta: Elmatera Publishing.

H.P., Achmad. (2008). Sintaksis Bahasa Indonesia. Jakarta: Fakultas Bahasa dan Seni Universitas Negeri Jakarta.
Putrayasa, I. B. (2007). Kalimat Efektif. Bandung: Refika Aditama.

Rosidi, I. (2009). Menulis, Siapa Takut. Yogyakarta: Kanisius.

Sugiyono. (2010). Metode Penelitian Kuantitatif Kualitatif Research and Development. Bandung : Alfabeta

Sumarlam, dkk. (2003). Teori dan Praktik Analisis Wacana. Surakarta: Pustaka Cakra.

Tarigan, H. G. dan Djago. (2009). Membina Keterampilan Menulis Paragraf dan Pengembangannya. Bandung: Angkasa.

------. (2011). Pengajaran Analisis Kesalahan Berbahasa. Bandung: Angkasa.

Tarigan, H.G. (2009). Pengajaran Morfologi. Bandung: Angkasa. (2009). Pengajaran Sintaksis. Bandung : Angkasa

(2011). Pengajaran Analisis Konstrastif Bahasa. Bandung: Angkasa. 